\title{
Assessment of Genome Damage in Bird and Mammal Species as a Tool for Improvements in ex-situ Conservation at Zoos
}

\author{
Mônica Lúcia Adam ${ }^{1,2 *}$, Rodrigo Augusto Torres², Marina Kiska ${ }^{3}$, \\ Fernanda Ferraz Oliveira ${ }^{3}$, Oneida Lacerda ${ }^{4}$, Graziela Sponchiado ${ }^{3}$, \\ Cíntia Mara Oliveira Ribas ${ }^{5} \&$ Maria Tereza dos Santos Correia ${ }^{6}$
}

\author{
${ }^{1}$ Universidade Federal de Pernambuco - UFPE, Vitória de Santo Antão, PE, Brazil \\ ${ }^{2}$ Laboratório de Genômica Evolutiva e Ambiental, Departamento de Zoologia, Centro de Ciências Biológicas, \\ Universidade Federal de Pernambuco - UFPE, Recife, PE, Brazil \\ ${ }^{3}$ Núcleo de Ciências Biológicas e da Saúde - NCBS, Laboratório de Citogenética, Universidade Positivo - UP, \\ Curitiba, PR, Brazil \\ ${ }^{4}$ Departamento de Zoológico, Zoológico Municipal de Curitiba, Prefeitura Municipal de Curitiba, PR, Brazil \\ ${ }^{5}$ Núcleo de Ciências Biológicas e da Saúde - NCBS, Laboratório de Controle de Qualidade, Universidade Positivo - UP, \\ Curitiba, PR, Brazil \\ ${ }^{6}$ Programa de Pós-graduação em Ciências Biológicas, Centro de Ciências Biológicas, \\ Universidade Federal de Pernambuco - UFPE, Recife, PE, Brazil
}

\begin{abstract}
Ex-situ conservation at zoos requires strategies regarding improvements to enclosures, as ex-situ conserved specimens constitute an effective reservoir for genetic and biological restoration. The present study focuses on the management of enclosures at zoos and offering an accurate, fast and inexpensive procedure for ex-situ conservation through the assessment of the degree of genome damage (micronuclei) in different bird and mammal species. Analyses of variance revealed statistically significant differences in both bird and mammal species, in comparison to their reference groups. All bird species and Tapirus terrestris had high proportional micronucleus indexes, indicating high susceptibility to genome damage through contact with polluted water from the river used to supply the enclosures. Recognizing the relationship between water quality (evaluated at entry and exit of water in the zoo) and habitat deterioration as well as individual responses to these factors in terms of genotoxicity make efforts directed at ex-situ conservation an urgent priority.
\end{abstract}

Key words: Captivity, ex-situ Conservation, Genotoxicity, Micronuclei, Pollution, Zoos.

\section{Introduction}

Currently, there is widespread concern regarding biodiversity and the main threats to this diversity stem from human activities. Contact with pollution affects air and water quality as well as the global climate. Pollution is a major cause of concern worldwide (Primack \& Rodrigues 2001). Nations are faced with environment contamination as a consequence of exposure to toxic waste and polluted air, water and food pollution as well as pollutants from disasters (Peres 2005).

*Send correspondence to: Mônica Lúcia Adam

Laboratório de Genômica Evolutiva e Ambiental,

Departamento de Zoologia, Centro de Ciências

Biológicas, Universidade Federal de Pernambuco - UFPE,

Av. Prof. Moraes Rego, s/n, Cidade Universitária,

CEP 50670-420, Recife, PE, Brazil

E-mail: mladam@yahoo.com
Water pollution has negative consequences for all organisms. Rivers, lakes and oceans are frequently used as dumping grounds for industrial and residential waste. Even at low concentrations, lethal amounts of toxic chemicals can be absorbed by the aquatic organisms that filter large volumes of water. Mammal and bird species that feed on these filtering organisms are exposed to more concentrated levels of toxic elements (Primack \& Rodrigues 2001; Baptista-Neto et al. 2008). The best strategy for mitigating the effects of pollution is the constant monitoring of the populations in the wild or in artificial environments, such as zoological parks (Primack \& Rodrigues 2001).

Zoos around the world have started acting in a conservation fashion through breeding in captivity, environmental education and zoological research. In of research terms, great improvement has been achieved in preserving genetic 
diversity from endogamy (Laikre 1999). Such an approach consists of the use of genetic analyses for species preservation focused on faunistic restoration capable of responding to environmental transformations and minimizing the risk of extinction (Frankham et al. 2002). Effective population size is one of the main concerns in population biology. The genetic diversity of a species is extremely threatened when its effective population size is reduced, especially when the biota is submitted to rapid, unusual changes in the environment (Primack \& Rodrigues 2001; Frankham et al. 2002). This is the most traditional situation of populations at zoos and provides the conditions for the loss of reservoirs of biological diversity in terms of genetic variation.

Considering the importance of constant monitoring, genotoxic studies provide fast, accurate, inexpensive procedures for determining responses to putative contaminations. Such studies allow evaluating the effect of substances on cells, tissues and organs and deducing the causes and effects of metabolic disturbances (Padrangi et al. 1995; Adam et al. 2005; Ergene et al. 2007; Adam et al. 2010).

Despite of its widespread use in the evaluation of contaminants, the micronucleus test has received minimal attention in genotoxic evaluations of in-situ and ex-situ conservation issues (Meier et al. 1999). Two seminal studies have been carried out on captive species (domestic) in order to evaluate putative DNA damage (micronuclei frequency) through intense medicinal administrations (Cristaldi et al. 2004; Adam et al. 2005). The micronucleus test is able to demonstrate chromatin loss as a consequence of chromosome damage throughout the mitotic phases. Such damage gives rise to fragments of genetic material on basal levels through the mechanical effects of mitosis in which damaged cells are eliminated (Kirsh-Volders 1997). In counterpart, an increased frequency of micronucleated cells suggests the effect of some unusual environmental component on normal physiology, thereby decreasing adaptation to fast, drastic changes in natural or artificial environments (Padrangi et al. 1995).

The aim of the our study was to determine the frequency of micronuclei in different captive species submitted to polluted water from the Iguaçu River (Curitiba/Brazil) on a daily basis. Such approach can be addressed to the management of captive environments at zoos and offer an accurate, fast, inexpensive procedure for ex-situ conservation. Additionally, microbiological analyses were carried out in order to determine possible associations between the frequency of micronuclei and putative fecal contamination.

\section{Material and Methods}

We conducted our study in the Zoological Park located in the metropolitan area of Curitiba (Paraná - Brazil) near the Iguaçu River. The zoo uses water from the river and other water springs to supply the enclosures. Iguaçu River in the study area is frequently affected by urban pollution.
Two groups of species were studied separately using the micronucleus test. The choice of species for analysis was based on the criterion of enclosure location in relation to the entry, circulation and exiting of water used. Four bird (Amazona brasiliensis, Cygnus atratus, Dendrocygna viduata, and Netta peposaca) and mammal (Cebus apella, Lama glama, Mazama gouazoubira, and Tapirus terrestris) species were analyzed. Blood samples were obtained from four specimens of each species and the smears were stained with a $100 \%$ Giemsa solution for four to eight minutes.

The frequency of micronuclei was determined by analyzing three thousand cells per specimen. Frequencies were compared by using one-way analysis of variance (ANOVA) with specific basal and normal-like frequency (control value) of micronuclei found in the literature, according to Zúñiga et al. (1996) and Zúñiga-González et al. 2000; 2001. The criteria used for defining the reference groups were the close phylogenetic relationships and shared or at least similar habits regarding feeding, behavior, metabolism and habitat.

The data were log-transformed and homocedasticity was tested using Bartlett's test. The data were also analyzed using the Kruskal-Wallis test (non-parametric ANOVA) when variance was non-homogeneous $(\mathrm{p}<5 \%)$. The detection of differential genotoxic impact on the species analyzed was carried out by comparing the mean number of micronuclei in the study group and control group of the species studied.

Water quality was determined using microbiological procedures, following the current guidelines of CONAMA (2005) (Brazilian Environmental Council) 357/05 class 3 $(>1,000 \mathrm{Nmp} / 100 \mathrm{~mL})$. Water was sampled from the water entry and exit sites of the Iguaçu River in the Zoo. The water circulating within the entire set of the enclosures was also analyzed.

\section{Results}

There was a varying frequency of micronuclei in both inter-species and intra-species terms among the bird and mammal species (Table 1). The number of micronuclei in the mammal species ranged from 14 to 86 in Cebus apella, from 20 to 52 in Lama glama, from 17 to 32 in Mazama gouazoubira, and from 15 to 93 in Tapirus terrestris. Among the bird species, the number of micronuclei ranged from 34 to 56 in Amazona brasiliensis, from 3 to 31 in Cygnus atratus, from 5 to 18 in Dendrocygna viduata, and from 5 to 50 in Netta peposaca. ANOVA comparisons with the control groups revealed statistically significant differences for all species (Table 2).

The proportional micronucleus indexes among the species (compared to control) revealed the following decreasing order of proportion for bird species: Amazona brasiliensis (149.01 and 95.97), Netta peposaca (131.66), Cygnus atratus (85.0) and Dendrocygna viduata (78.33). Among the mammal species, the following decreasing order of proportion was 
Table 1. Number of normal and micronucleated cells, media of micronucleated cells and frequencies of micronucleated cells in bird and mammal species studied.

\begin{tabular}{|c|c|c|c|c|c|c|c|}
\hline Bird species & $\mathrm{NC}$ & MNC & $\mathbf{F}$ & Mammal species & NC & MNC & $\mathbf{F}$ \\
\hline Amazona brasiliensis & 2,966 & 34 & 34 & Cebus apella & 2,960 & 40 & 0.013 \\
\hline Amazona brasiliensis & 2,960 & 40 & 40 & Cebus apella & 2,914 & 86 & 0.029 \\
\hline Amazona brasiliensis & 2,944 & 56 & 56 & Cebus apella & 2,986 & 14 & 0.005 \\
\hline Amazona brasiliensis & 2,965 & 35 & 35 & Cebus apella & 2,890 & 15 & 0.005 \\
\hline Mean & & 41.25 & 41.25 & Mean & & 38.75 & \\
\hline Cygnus atratus & 2,969 & 31 & 31 & Lama glama & 2,980 & 20 & 0.007 \\
\hline Cygnus atratus & 2,995 & 5 & 5 & Lama glama & 3,060 & 44 & 0.014 \\
\hline Cygnus atratus & 2,997 & 3 & 3 & Lama glama & 2,972 & 34 & 0.011 \\
\hline Cygnus atratus & 2,988 & 12 & 12 & Lama glama & 2,948 & 52 & 0.017 \\
\hline Mean & & 12.75 & 12.75 & Mean & & 37.5 & \\
\hline Dendrocygna viduata & 2,992 & 8 & 8 & Mazama gouazoubira & 973 & 27 & 0.027 \\
\hline Dendrocygna viduata & 2,995 & 5 & 5 & Mazama gouazoubira & 983 & 17 & 0.017 \\
\hline Dendrocygna viduata & 2,984 & 16 & 16 & Mazama gouazoubira & 1,000 & 32 & 0.031 \\
\hline Dendrocygna viduata & 2,982 & 18 & 18 & Mazama gouazoubira & 2,979 & 21 & 0.007 \\
\hline Mean & & 11.75 & 11.75 & Mean & & 24.2 & \\
\hline Netta peposaca & 2,950 & 50 & 50 & Tapirus terrestris & 2,954 & 51 & 0.017 \\
\hline Netta peposaca & 2,995 & 5 & 5 & Tapirus terrestris & 2,907 & 93 & 0.031 \\
\hline Netta peposaca & 2,992 & 8 & 8 & Tapirus terrestris & 2,949 & 51 & 0.017 \\
\hline Netta peposaca & 1,984 & 16 & 16 & Tapirus terrestris & 3,080 & 15 & 0.004 \\
\hline Mean & & 19.75 & 19.75 & Mean & & 52.5 & \\
\hline Total & 46,658 & 342 & 342 & & 41,535 & 612 & 0.014 \\
\hline
\end{tabular}

NC - normal cells; MNC - micronucleated cells; F - Frequency.

Table 2. ANOVA results on number of micronuclei in bird and mammal species studied and those reported by Zúniga et al. (1996) and Zúñiga-González et al. (2000; 2001).

\begin{tabular}{lc}
\hline \multicolumn{1}{c}{ Species } & $\boldsymbol{P}$ \\
\hline Birds & 0.001 \\
Amazona brasiliensis $\times$ Amazona sp. & 0.002 \\
Amazona brasiliensis $\times$ Amazona finchi & 0.009 \\
Cygnus atratus $\times$ Dendrocygna viduata $\times$ Netta & \\
peposaca $\times$ Cygnus sp. & \\
Mammals & 0.002 \\
Cebus apella $\times$ Cebus sp. & 0.009 \\
Lama glama $\times$ Lama glama glama & 0.001 \\
Mazama gouazoubira $\times$ Odocolleus virginianus & $>0.001$ \\
Tapirus terrestris $\times$ Equus asinus & $>0.001$ \\
\hline Tapirus terrestris $\times$ Equus caballus & \\
\hline
\end{tabular}

detected: Tapirus terrestris (122.09 and 109.37), Lama glama (50.0), Mazama gouazoubira (14.43) and Cebus apella (6.03). The entire set of species analyzed had the following decreasing order of proportion of micronuclei: Amazona brasiliensis, Netta peposaca, Tapirus terrestris, Cygnus atratus, Dendrocygna viduata, Lama glama, Mazama gouazoubira and Cebus apella. Table 3 displays the mean micronucleus values and the respective proportional micronucleus indexes.
The microbiological analyzes (based on CONAMA 375/05 class 3 (2005)) revealed fecal and total coliform values above $1,000 \mathrm{NMP} / 100 \mathrm{~mL}$ in water entering the zoo (Table 4). Conversely, fecal and total coliform values $(700 \mathrm{nmp} / 100 \mathrm{~mL}$ and $1,100 \mathrm{nmp} / 100 \mathrm{~mL}$, respectively) for the water exiting the zoo were similar to those permitted by CONAMA (2005) (Table 4).

\section{Discussion}

A number of studies have been carried out for a better understanding of the role chemical substances play in ecosystems as well as how and where they occur in the environment, their interactions, effects on the biota and duration in the environment (Ferraro et al. 2004). However, little attention has been given to chemical substances and their effect on the quality of enclosure environments at zoos, which are home to many rare and often threatened animal species.

At the Curitiba Zoo, the greatest threat comes from the use of water from the Iguaçu River to supply enclosures, considering the known pollution of the river in the region. The microbiological analyses carried out at the water entry and exit points in the zoo detected the presence of total and fecal coliforms (Table 4). Sewage and the accumulation of rainwater are considered indications of chemical and/ or biological pollution (Ambrozevicius \& Abessa 2008). 
Table 3. Mean number of micronuclei and proportional micronuclei indexes for the species studied in comparison to reference groups.

\begin{tabular}{lccc}
\hline \multicolumn{1}{c}{$\begin{array}{c}\text { Species } \\
\text { (studied group } \times \text { control group) }\end{array}$} & $\begin{array}{c}\text { Mean number of } \\
\text { micronuclei } \\
\text { (control group) }\end{array}$ & $\begin{array}{c}\text { Mean number of } \\
\text { micronuclei } \\
\text { (study group) }\end{array}$ & $\begin{array}{c}\text { Index of } \\
\text { proportionality }\end{array}$ \\
\hline Amazona brasiliensis $\times$ Amazona sp. & 0.28 & 41.25 & 147.32 \\
Amazona brasiliensis $\times$ Amazona finchi & 0.435 & 41.25 & 94.82 \\
Cygnus atratus $\times$ Cygnus sp. & 0.15 & 12.75 & 85.0 \\
Dendrocygna viduata $\times$ Cygnus sp. & 0.15 & 11.75 & 78.33 \\
Netta peposaca $\times$ Cygnus sp. & 0.15 & 19.75 & 131.66 \\
Cebus apella $\times$ Cebus sp. & & & 6.03 \\
Lama glama $\times$ Lama glama glama & 6.42 & 38.75 & 50.0 \\
Mazama gouazoubira $\times$ Odocolleus virginianus & 0.75 & 37.5 & 14.43 \\
Tapirus terrestris $\times$ Equus asinus & 1.68 & 24.25 & 109.37 \\
Tapirus terrestris $\times$ Equus caballus & 0.48 & 52.5 & 122.09 \\
\hline
\end{tabular}

Table 4. Microbiological analyses based on CONAMA 357/05 (2005) class 3 at water entry and exit sites in the zoo.

\begin{tabular}{ccc}
\hline Locations of & \multicolumn{2}{c}{ Coliforms } \\
\cline { 2 - 3 } water sampling & Fecal & Total \\
\hline Entry & $1,700 \mathrm{nmp} / 100 \mathrm{~mL}$ & $7,000 \mathrm{nmp} / 100 \mathrm{~mL}$ \\
Exit & $700 \mathrm{nmp} / 100 \mathrm{~mL}$ & $1,100 \mathrm{nmp} / 100 \mathrm{~mL}$ \\
\hline
\end{tabular}

The occurrence of lesser concentrations of coliforms at the water exit point may be explained by possible dilution of the water in the zoo by some additional source of water, such as the stream water springs flowing through the area. This notion is further supported by the results of micronucleus frequencies in the mammal and bird species analyzed, as higher proportions of micronuclei were found in species in enclosures nearer to the entrance point of water from the Iguaçu River (Table 4). The exception was Amazona brasiliensis, which had the highest proportional micronucleus indexes. Thus, the occurrence of a possible genotoxic gradient is suggested in the distribution of the enclosures, possibly mediated by the distance from the point of water capture. This hypothesis is supported by the statistical significance obtained with ANOVA (Table 2) and by the proportional micronucleus indexes (Table 3 ). The enclosure for Cebus apella seems to be the one with the best water conditions, as this species had the lowest index of proportional micronucleated cells (Table 3 ). This circumstance may also be a consequence of additional water apart from the Iguaçu River diluting possible genotoxic agents. However, the statistical significance of the frequency of micronucleated cells does not discard a positive genotoxic status of the species.

The results for Cebus apella indicate additional important evidence regarding the management of enclosures in terms of their location and the ongoing genotoxicity in the species. The Cebus apella control group had one of the higher basal frequencies of micronucleated cells (Table 3). This classifies Cebus apella as possibly the most susceptible to genotoxic impact among the species studied. Thus, placing more sensitive species in locations in which genotoxic agents are diluted may be a positive conduct in terms of the ex-situ conservation of the species. Despite its proximity to the water capture point, the enclosure for Dendrocygna viduata also seems to be well located, as demonstrated by the lowest proportional micronucleus indexes among bird species, which suggests high tolerance to genotoxic conditions. Thus, placing more tolerant species in locations with high harboring of genotoxic agents may also be a positive conduct in terms of the ex-situ conservation of such species. However, considering the positive genotoxic status of the species, water quality in the enclosures should not be overlooked.

In both cases, the differences in genotoxic responses may reside in the inherent biology of these species submitted to similar selective pressure (Zúñiga et al. 1996; Meier et al. 1999; Ferraro et al. 2004; Newman 2001). Analyzing the expression of micronucleated cells in intra-species terms, Mazama gouazoubira achieved the lowest mean values of micronucleated cells (Tables 1 and 3), which may be related to the low metabolic rate of the species in artificial environments. Low metabolic rate seems to be related to a low mitotic index and low expression of micronucleated cells. The other mammal species analyzed exhibit an evident active behavior in artificial environments (personal observations from veterinarians), suggesting a high mitotic index and a high mean number of micronuclei (Tables 1 and 3 ). Such a result could be the consequence of an increase in metabolic oxiradicals caused by high metabolic rates. Inherent metabolic rates on the individual or species level may result in a different expression of micronuclei (Meier et al. 1999). Further evidence for such a hypothesis is found in the different micronucleus frequencies in the peripheral blood samples among 35 different mammal species (Zúñiga et al. 1996).

A close evolutionary relationship between cell morphology and physiology may predict similar cell responses (Withers 
1992; Willmer et al. 2009). For instance, substances that induce the formation of micronuclei in mammals may not do the same in birds. Moreover, differences in the genetic/ biochemical pool of the DNA repair system may be decisive in the expression of micronuclei (Newman 2001). These aspects may explain the inter-specific variability in the frequency of micronuclei between both biological groups analyzed.

Bird species had higher proportional micronucleus indexes (Table 3) than mammal species, with exception of Tapirus terrestris. This suggests a more intensive genotoxic response in species associated to aquatic environments, as in the cases of Netta peposaca, Cygnus atrattus, Dendrocygna viduata and Tapirus terrestris (Table 3). These species were therefore more susceptible to genotoxic agents from the Iguaçu River. It is recommended that the enclosures for aquatic bird and mammal species be located farther from the point of water entry and/or the use of alternative water supplies in order to minimize genotoxic effects. Studies should also be carried out on cellular kinetics in the erythrocytes of birds and mechanisms regarding the exclusion of micronucleated cells in the blood of both biological groups. According to Meier et al. (1999) and Grisolia and Cordeiro (2000), low frequencies of micronucleated erythrocytes may be an indication of their removal from the circulating blood by the spleen. Such studies would be important in terms of a better identification of more susceptible species as well as more effective bioindication.

Environmental pollution increases the incidence of mutations in populations. Although it is difficult to predict the consequences of such mutations, the changes in the gene pool due to genotoxic stress might affect the fitness of individuals and entire populations (Bol'shakov \& Moiseenko 2009; Bickham 2011). According to Mulvey and Diamond (1991), individuals with good biological fitness in polluted environments may be sufficiently heterozygous. Heterozygosity or genetic variability is the main biological component to be preserved (Moritz 2002). As many species found at zoos are endangered, the determination of their genotoxic status should be a mandatory routine at zoos around the world in order to improve quality of life in captivity. The high number of micronucleated cells observed in the present study demonstrated the need for improving the quality of the enclosures at the Curitiba Zoo in terms of the provisioning of water. Such measures would be very important because these animals are frequently candidates for captive breeding. While the animals analysed herein showed a genetic instability in their genomes, it might be related to their morbity and their resulting exclusion from breeding programs. In addition the genotoxicity observed in the somatic cells from the species studied herein suggest a possible similar phenomenon occuring at their gametes. Abormal germ cells normally lead to heritable mutations, embryonic death or at least anatomical/morphological abnormalities in the offsspring (Bol'shakov \& Moiseenko 2009). Therefore such reasoning indicates some of the detrimental aspects regarding successful programs of biodiversty preservation at Zoos.

The species Amazona brasiliensis needs particular attention, as its inclusion in the study was based on the fact that its enclosure does not receive water from the Iguaçu River and it could therefore be used as a control group for the analyses. Surprisingly, analysis revealed considerable genome damage (Tables 1, 2 and 3), suggesting an additional genotoxic agent affecting the species, such as stress. This phenomenon has been indicated as a powerful cause of genotoxicity (Fischman et al. 1996; Adam et al. 2011). Evidence of the genotoxic effect of stress in Amazona brasiliensis was found in the fact that specimens were found pulling out their abdominal feathers. These results further reinforce the role of zoos as institutions responsible for the maintenance of breeding colonies of rare and endangered species for captive breeding programs (Primack \& Rodrigues 2001) and efforts should be directed at the maintenance of the genome stability for the success of such programs.

Therefore, recognizing the relationship between water quality and habitat deterioration as well as individual responses to these factors in terms of genotoxicity make efforts directed at ex-situ conservation an urgent priority. The results of the present study demonstrate such reasoning with regard to the monitoring of target species focused on maintaining their biological integrity in captivity at zoos around the world.

\section{Acknowledgments}

The authors are grateful for the important contributions provided by Dr. Lucyenni Gisele Popp Brasil Queiroz (Zoo Park of Curitiba, PR, Brazil) and Dr. José Roberto Botelho de Souza (Departamento de Zoologia, UFPE, Recife, Brazil).

\section{References}

Adam ML et al., 2005. Genotoxity of nitroxynil and moxydectin in sheep. Online Journal of Veterinary Research, 9(2):84-87.

Adam ML et al., 2010. Environmental Degradation at a Public Park in Southern Brazil as revealed Through a Genotoxicity Test (MN) on Peripheral Blood Cells from Poecilia vivípara (Teleostei). Water, Air and Soil Pollution, 211(1):61-68. http://dx.doi.org/10.1007/s11270-009-0280-9

Adam ML et al., 2011. On the stress by photoperiod, temperature and noise as possible causes of genomic damaging in an animal model. Stress and Health, 27:e152-e156. http:// dx.doi.org/10.1002/smi.1350

Ambrozevicius AP \& Abessa DMS, 2008. Acute toxicity of waters from the urban drainage channels of Santos (São Paulo, Brazil). Panamjas, 3(2):108-115.

Baptista-Neto JA, Wallner-Kersanach M \& Patchineelam SM, 2008. Poluição Marinha. Rio de Janeiro: Interciência.

Bickham JW, 2011. The four cornerstones of Evolutionary Toxicology. Ecotoxicology, 20:497-502. PMid:21424723. http://dx.doi.org/10.1007/s10646-011-0636-y 
Bol'shakov VN \& Moiseenko TI, 2009. Anthropogenic Evolution of Animals: Facts and Their Interpretation. Russian Journal of Ecology, 40(5):305-313. http://dx.doi.org/10.1134/ S1067413609050014

Conselho Nacional do Meio Ambiente - CONAMA. Resolução $n^{\circ}$ 357, de 17 de março de 2005. Dispõe sobre a classificação dos corpos de água e diretrizes ambientais para o seu enquadramento, bem como estabelece as condições e padrões de lançamento de efluentes, e dá outras providências. Diário Oficial da República Federativa do Brasil, DF, 18 mar. 2005. Available from: <http//www.mma.gov.br/pot/conama/res/ res05/res35750.pdf>. Access in: 20 May 2009.

Cristaldi M et al., 2004. Comparative evaluation of background micronucleus frequencies in domestic mammals. Mutation Research, 559:1-9. PMid:15066568. http://dx.doi. org/10.1016/j.mrgentox.2003.10.021

Ergene S et al., 2007. Monitoring of nuclear abnormalities in peripheral erythrocytes of three fish species from Goksu Delta (Turkey): genotóxico damage in relation to water pollution. Ecotoxicology, 16(4):385-391. PMid:17380383. http://dx.doi.org/10.1007/s10646-007-0142-4

Ferraro MVM et al., 2004. Mutagenic effects of tributylin and inorganic lead ( $\mathrm{PbII})$ on the fish $\mathrm{H}$. malabaricus as evaluated using the comet assay and the piscine micronucleos and chromosome aberration tests. Genetics and Molecular Biology, 27(1):103-107. http://dx.doi.org/10.1590/ S1415-47572004000100017

Fischman HK, Pero RW \& Kelly DD, 1996. Psychogenic stress induces chromosomal and DNA damage. International Journal of Neuroscience, 84:219-227. PMid:8707484. http:// dx.doi.org/10.3109/00207459608987267

Frankham R, Ballou JD \& Briscoe DA, 2002. Introduction to Conservation Genetics. Cambrigde, New York. PMid:12126990. http://dx.doi.org/10.1017/ CBO9780511808999

Grisolia CK \& Cordeiro CMT, 2000. Variability in micronucleous induction with different mutagens applied to several species of fish. Genetics and Molecular Biology, 23(1):235-239. http:// dx.doi.org/10.1590/S1415-47572000000100041

Kirsh-Voldres M, 1997. The validation of the micronucleus test. Mutation Research, 392:1-4. http://dx.doi.org/10.1016/ S0165-1218(97)00039-6

Laikre L, 1999. Hereditary defects and conservation genetic management of captive populations. Zoo
Biology, 18(2):81-99. http://dx.doi.org/10.1002/ (SICI) 1098-2361(1999)18:2<81::AID-ZOO1>3.0.CO;2-2

Meier JR, Wernsing P \& Torsella J, 1999. Feasibility of micronucleus methods for monitoring damage in two feral species of small mammals. Environmental and Molecular Mutagenesis, 33:219-225. http://dx.doi.org/10.1002/ (SICI)1098-2280(1999)33:3<219::AID-EM6>3.0.CO;2-X

Moritz C, 2002. Strategies to protect biological diversity and the processes that sustain it. Systematic Biology, 51:238-254. PMid:12028731. http://dx.doi. org/10.1080/10635150252899752

Mulvey M \& Diamond SA, 1991. Genetics factors and tolerance acquisition in populations exposed to metals and metalloids. In: Newman MC \& MacIntosh AW (eds.). Metal Ecotoxicology: concepts and applications. Advances in trace substances research series. Chelsea: Lewis Publishers, Inc. p. 301-321.

Newman MC, 2001. Fundamentals of Ecotoxicology. New York: Lewis Publishers.

Padrangi R et al., 1995. Alkaline single cell gel (comet) assay and genotoxicity monitoring using bullheads and carps. Environmental and Molecular Mutagenesis, 26:345-356. http://dx.doi.org/10.1002/em.2850260411

Peres RM, 2005. Contaminação ambiental e malformação congênita na América Latina. Porto Alegre: Supplement.

Primack RB \& Rodrigues E, 2001. Biologia da Conservação. Londrina: Planta.

Withers CP, 1992. Comparative Animal Physiology. New York: Saunders College Publishing.

Willmer P et al., 2009. Environmental Physiology of Animals. Oxford: Blackwell Publishing.

Zúñiga G et al., 1996. Spontaneous micronuclei in peripheral blood erythrocytes from 35 mammalian species. Mutation Research, 369:123-127. http://dx.doi.org/10.1016/ S0165-1218(96)90056-7

Zúñiga-González G et al., 2000. Spontaneous micronuclei in peripheral blood erythrocytes from 54 species (mammals, reptiles and birds): Part two. Mutation Research, 467:99-103. http://dx.doi.org/10.1016/S1383-5718(00)00021-8

Zúñiga-González G et al., 2001. Differences in the number of micronucleated erythrocytes among young and adult animals including human spontaneous micronuclei in 43 species. Mutation Research, 494:161-167. http://dx.doi. org/10.1016/S1383-5718(01)00180-2 